\title{
Knowledge and attitudes of infection prevention and control among health sciences students at University of Namibia
}

\author{
*Ojulong $\mathrm{J}^{1}$, Mitonga $\mathrm{KH}^{2}$, lipinge $\mathrm{SN}^{3}$
}

1. Department of Microbiology, School of Medicine, University of Namibia, Windhoek, Namibia.

2. Department of Community Medicine, School of Medicine, University of Namibia, Windhoek, Namibia.

3. Schools of Nursing and Public Health, University of Namibia, Windhoek, Namibia

\begin{abstract}
Background: Health Sciences students are exposed early to hospitals and to activities which increase their risk of acquiring infections. Infection control practices are geared towards reduction of occurrence and transmission of infectious diseases.

Objective: To evaluate knowledge and attitudes of infection prevention and control among Health Science students at University of Namibia.

Methods: To assess students' knowledge and attitudes regarding infection prevention and control and their sources of information, a self-administered questionnaire was used to look at standard precautions especially hands hygiene.

Results: One hundred sixty two students participated in this study of which 31 were medical, 17 were radiography and 114 were nursing students. Medical students had better overall scores (73\%) compared to nursing students $(66 \%)$ and radiology students $(61 \%)$. There was no significant difference in scores between sexes or location of the high school being either in rural or urban setting.

Conclusion: Serious efforts are needed to improve or review curriculum so that health sciences students' knowledge on infection prevention and control is imparted early before they are introduced to the wards.
\end{abstract}

Key words: Infection Prevention and Control, Health Science students, Hand hygiene.

African Health Sciences 2013; 13(4): 1071 - 1078 http://dx.doi.org/10.4314/ahs.v13i4.30

\section{Introduction}

Poor hospital hygiene has been widely publicized, including patients' concerns about safety in hospitals. This has made infection control a hot topic in clinical practice, the media and the community at large. The main purpose of infection control is to reduce the occurrence and transmission of infectious diseases. Specialized training must be received before a health sciences student undertakes any patient procedure involving sharp devices ${ }^{1}$.

Health Sciences students are exposed early to the hospitals and to activities which increase their risk of acquiring and transmitting infections. These diseases are usually caused by bacteria or viruses and can be spread from health worker to patient or vice versa through contact - human contact with an infected surface, airborne transmission through droplets and/or aerosols and, finally, by common vehicles as food or water. Exposure to infectious

\begin{tabular}{|l|}
\hline *Corresponding author: \\
Julius Ojulong \\
Department of Microbiology, School of Medicine \\
University of Namibia \\
Windhoek, Namibia. \\
Tel (W) : +264612065018 \\
Cell: +264817499586 \\
Email: jojulong@gmail.com; jojulong@unam.na \\
\hline
\end{tabular}

diseases is one of the most frequently identified occupational hazards facing health care workers. The early provision of training programs that provides information about protecting medical students from exposure to blood borne pathogens is therefore appropriate and is of paramount importance ${ }^{2}$.

Unlike in developed countries where the prevalence of infectious diseases including HIV and TB are low, the risk for medical students to occupationally acquire a serious disease is usually high and is a major concern, especially for the medical educational institutions in Namibia. The prevalence of HIV in Namibia is $18.8 \%$ among ante-natal clinic attendees (MoHSS, 2010) and 56\% among TB patients (MoHSS, 201133). Namibia has an alarmingly high TB burden reporting 12625 TB patients in 2010 with a notification rate of 589 cases per 100,000 population, one of the highest in the world ${ }^{3}$. The potential to transmit TB, for example, in hospitals is high as a confirmed high incidence of TB possesses a substantial high risk for transmission ${ }^{4}$.

The highest prevalence rates of hepatitis B virus (HBV) have been reported from Southeast Asia and sub-Saharan Africa ${ }^{5}$. There is no current information on the prevalence of HBV in Namibia but we believe that the prevalence of chronic (HBV) 
infection in Namibia is known to be high in adults as reported by the Namibian National Blood Transfusion Service. In fact, a prevalence rate of $14.8 \%$ were reported on markers of current HBV infection and $53 \%$ on markers for past exposure to $\mathrm{HBV}^{6}$.

This situation intensifies the need for a comprehensive curriculum to be introduced early in the training of health sciences students to incorporate prevention and control of infectious diseases. Hand hygiene is an important healthcare issue globally and is the single most cost-effective and practical measure to reduce the incidence of healthcare-associated infection and the spread of antimicrobial resistance across all settings from advanced health care systems to primary healthcare centers as well as to health workers ${ }^{7,8}$.

The first health services in Namibia were established in the 1890's in Windhoek and Swakopmund to serve German soldiers. Soon after, Finnish missionaries set up several clinics in the north. Training of professional nurses was offered through the Nursing colleges in Oshakati and Windhoek hospitals until 1985. As a move in higher education became eminent, the Academy for Tertiary Education was established. The Faculty of Medical and Health Science was established at the Academy in January 1986 after a need was identified to train professional nurses in Namibia instead of depending on South Africa. This was the first University component for the Academy of the then South West Africa, now Namibia, in training health professionals. The Faculty offered mainly nursing sciences programmes until 1996 when the National Diploma in Radiography was introduced with the assistance of the World Health Organization.

After independence, the University of Namibia (UNAM) was established by Act of Parliament (Act 82 of 1992) on the $1^{\text {st }}$ of September 1992. A commission was set up to look into the issues of tertiary education in Namibia in 1991. One of its recommendations was to set up a consultative body to establish programmes for the Health Sciences. As such it recommended that a feasibility study for the development of the school of medicine should be undertaken. WHO was requested to support this initiative and a consultant was recruited, a report written but it was never implemented. However, in 2000 the UNAM introduced a pre-medical programme to prepare students in their first two years for medicine and pharmacy. After the premedical programme, the students were sent to medical universities in the Southern Africa Development Community (SADC). The first intake for the School of Medicine started in 2010 with an intake of 55 students. In 2013, it was established and soon the School of Public Health within the Faculty of Health Sciences.

All the health related health programmes in the Faculty are approved by the Senate and Health Professionals' Council of Namibia and are within the Namibian Framework of Qualifications. For all health care trainees, infection control is a subject in their programmes. The skills obtained are important to prevent the spread of infections and to promote health on a personal level as well as on macro-levels. Curriculum for health sciences students on infection control is introduced early but does not comprehensively tackle issues on infection control and prevention.

This study was done to evaluate the students' knowledge and attitude toward infection control and prevention.

Few studies in Africa, Sub-Saharan and southern Africa have reported on health sciences students' knowledge, attitudes and practices toward the infection prevention and control.

It is therefore important for a new Faculty of Health Sciences and particularly a new School of Medicine to monitor and continually assess the knowledge acquired by the students in different subjects in order to benchmark the standard and maintain the curricula levels.

\section{Methods}

This research was designed as a cross-sectional descriptive study which evaluated knowledge and attitudes of general principles of infection prevention and control of students in the Faculty of Health Sciences UNAM. For the purpose of this study the Bachelor of Medicine and Bachelor of Surgery (MBChB) students, nurses and radiographer students were regarded generally as health sciences students. Students were selected through non probability convenience sampling. A pre-designed, pre-tested, anonymous self-administered, semi-structured questionnaire was given to each student who had an informed consent to take part in the study. This questionnaire was adapted from a previous study done in France in four healthcare schools at Rouen University ${ }^{1}$. The questionnaire was pretested with more than ten respondents that included all students categories at the Faculty of Health Sciences of the 
University of Namibia. The survey was found suitable for use by Society for Healthcare Epidemiology of America in data collection. We have made necessary revisions and adaptation to Namibia context.

The questionnaire was composed of two parts. The first part collected demographics of the students and the second part evaluated whether the current infection control and practices were in line with standard precautions recommended by World Health Organization (WHO). ${ }^{7}$

The range of possible scores was 0 to 100 . The survey and data collection received the approval of the ethics committee of the Faculty of Health Sciences.

For the analysis, the data were entered into Statistical Package for Social Science (SPSS) version 20 by two researchers and checked for errors. Frequencies and percentages were derived for categorical variables. To estimate univariate associations, differences in proportions were assessed by using the chi-square test. Analysis of variance (ANOVA) was performed to compare the infection prevention and control (IPCs) Knowledge score considering three variables (student group, gender, high school origin) and their interactions. We verified that the data complied with ANOVA model assumptions of normality (Shapiro-Wilk test) and equal variance (Levene test). The least square difference method (LSD) was used as a Post-hoc test to assess the significance of difference of the infection prevention and control score among the different groups of students. All p-values were two sided and considered statistically significant if $<0.05$.

\section{Results}

A total of 162 health sciences students in their $2^{\text {nd }}$ or $3^{\text {rd }}$ year of study participated in this study among which 114 Nursing students, 31 were Medical students and 17 were radiographers. The students' characteristics related to the age, gender, high school of origin are summarized in table 1.

The means of IPC knowledge score and the $95 \%$ confidence intervals for female and male students are described in the table 2.

Table 1: Descriptive statistics of students

\begin{tabular}{lllllll}
\hline $\begin{array}{l}\text { Student } \\
\text { Group }\end{array}$ & Total & $\begin{array}{l}\mathbf{9 5 \%} \mathbf{C I} \\
\text { Mean age }\end{array}$ & Male (\%) & $\begin{array}{l}\text { Female } \\
\mathbf{( \% )}\end{array}$ & $\begin{array}{l}\text { Rural high } \\
\text { school } \\
\mathbf{( \% )}\end{array}$ & $\begin{array}{l}\text { Urban } \\
\text { high } \\
\text { school (\%) }\end{array}$ \\
\hline Medicine & 31 & $22.4 \pm 1.2$ & 45.2 & 54.8 & 32.3 & 67.7 \\
Radiology & 17 & $22.4 \pm 1.7$ & 35.3 & 64.7 & 35.3 & 64.7 \\
Nursing & 114 & $25.1 \pm 1.1$ & 17.5 & 82.5 & 46.0 & 54.0 \\
TOTAL & 162 & $24.3 \pm 0.8$ & 24.7 & 75.3 & 42.2 & 57.8 \\
\hline
\end{tabular}

Table 2: Descriptive statistics of IPCknowledge score based on gender

\begin{tabular}{llllll}
\hline & N & Mean & $\begin{array}{c}\text { Std. } \\
\text { Error }\end{array}$ & \multicolumn{2}{c}{$\begin{array}{c}\mathbf{9 5 \%} \text { Confidence Interval for } \\
\text { Mean }\end{array}$} \\
\cline { 5 - 6 } & & & & $\begin{array}{c}\text { Lower } \\
\text { Bound }\end{array}$ & $\begin{array}{c}\text { Upper } \\
\text { Bound }\end{array}$ \\
\hline Female & 122 & 66.3 & 1.4 & 63.6 & 69.1 \\
Male & 40 & 67.6 & 2.2 & 63.3 & 72.1 \\
Total & 162 & 66.6 & 1.2 & 64.3 & 69.0 \\
\hline
\end{tabular}

We were interested in assessing the effect of three variables (student group, gender, high school origin) and their interactions on the students' infection prevention and control knowledge scores. The results in table 3 show that only student group was significant as a main effect $(p$-value $=0.023<0.05)$; the gender, the high school origin and the interactions were not significant ( $p$-values $>0.05)$.

The mean scores for Medicine students were higher than both Radiology and Nursing $(p<0.05)$ by ANOVA with LSD post hoc test as shown in table 4 and figure 1. 
Table 3: ANOVA results for overall IPC Knowledge Score for gender, student area, high school origin, and their interactions

\begin{tabular}{llllll}
\hline Source & $\begin{array}{l}\text { Type III } \\
\text { Sum of } \\
\text { Squares }\end{array}$ & df & $\begin{array}{l}\text { Mean } \\
\text { Square }\end{array}$ & F & Sig. \\
\hline Gender & 119 & 1 & 119 & 0.53 & .47 \\
Student & 1725 & 2 & 863 & 3.86 & .02 \\
School origin & 134 & 1 & 134 & 0.60 & .44 \\
Gender* Student & 52 & 2 & 26 & 0.11 & .89 \\
Gender* School origin & 43 & 1 & 43 & 0.19 & .66 \\
Student* School origin & 154 & 2 & 77 & 0.35 & .71 \\
Gender* Student* & 273 & 2 & 136 & 0.61 & .54 \\
School origin & & & & & \\
Error & 33264.337 & 149 & 223.251 & & \\
Total & 751024.250 & 161 & & & \\
Corrected total & 36246.261 & 160 & & & \\
\hline
\end{tabular}

a. $\mathrm{R}$ Squared $=.082$ (Adjusted R Squared $=.015)$

Table 4: LSD Post Hoc Tests - Multiple comparisons of means IPC knowledge scores

\begin{tabular}{ccccc}
\hline $\begin{array}{c}\text { (I) } \\
\text { Student }\end{array}$ & $\begin{array}{c}(\mathrm{J}) \\
\text { Student }\end{array}$ & $\begin{array}{l}\text { Mean } \\
\text { Difference } \\
(\mathrm{I}-\mathrm{J})\end{array}$ & Std. Error & p-value \\
\hline Medicine & Radiology & $11.9^{*}$ & 4.4 & .008 \\
& Nursing & $7.1^{*}$ & 2.9 & .019 \\
Radiology & Medicine & $-11.9^{*}$ & 4.4 & .008 \\
& Nursing & -4.9 & 3.8 & .207 \\
\hline
\end{tabular}

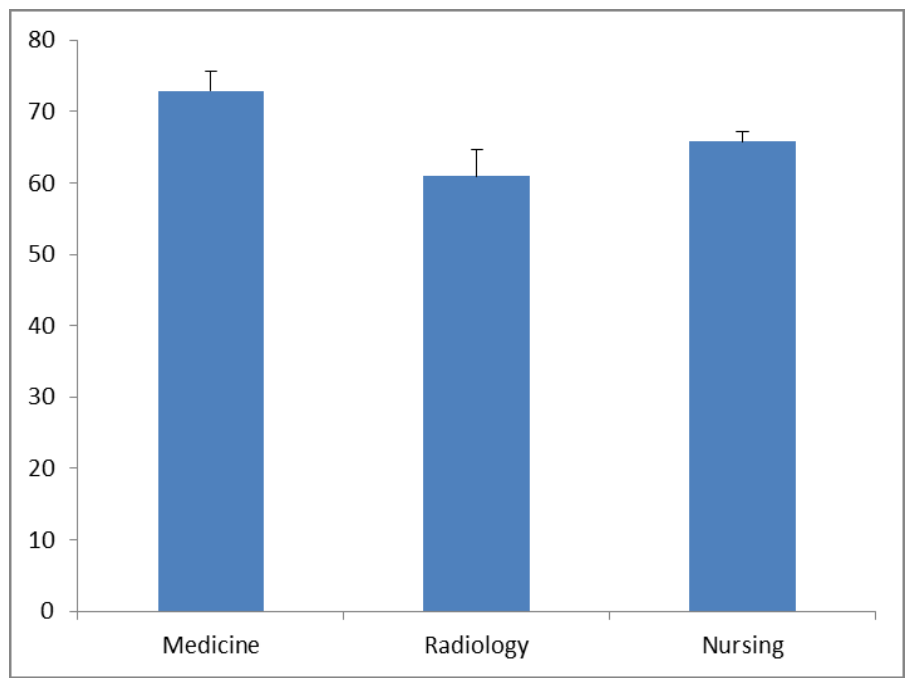

Figure 1: Mean (+SE) of KAIPC scores for each group of students

Group means were compared by ANOVA with LSD post hoc test. * Medicine significantly different from Radiology ( $p=0.008)$ and Nursing $(p=0.019)$.

Considering the specific questions related to Infection prevention and control, we are going to point out the most important or relevant results (table 5).

In our survey, only $24.1 \%$ of all respondents gave a correct answer to the question related to the environment (air, water, inert surfaces) as the major source of bacteria responsible for Nosocomial infection, $48.4 \%$ respondents among medical students, $6.0 \%$ respondents among the radiology students and $20.2 \%$ respondents among the nursing students. 
On the question relating to hand hygiene - the indications for the use of alcohol-based hand rub (on unsoiled hands), $33.9 \%$ of the respondents responded correctly $19.7 \%$ respondents among medical students, $58.9 \%$ respondents among the radiology students, $34.2 \%$ respondents among the nursing students.

In the use of protective barriers, the standard precautions recommend use of gloves for each procedure, when there is a risk of contact with the blood or body fluid, when there is a risk of a cut and when healthcare workers have a cutaneous lesion. $42.0 \%$ of all respondents gave a correct answer to this question, $58.1 \%$ of respondents among medical students, $41.2 \%$ respondents among the radiology students and $37.7 \%$ respondents among the nursing students.

Table 5: Percent correct to each survey item for all respondents and for each student group (Medicine, Radiology and Nursing)

\begin{tabular}{|c|c|c|c|c|}
\hline Infection prevention and control categories & $\begin{array}{c}\text { Total } \\
(\%)\end{array}$ & $\begin{array}{l}\text { Medicin } \\
\text { e (\%) }\end{array}$ & $\begin{array}{c}\text { Radiolo } \\
\text { gy } \\
(\%)\end{array}$ & $\begin{array}{c}\text { Nursing } \\
(\%)\end{array}$ \\
\hline $\begin{array}{l}\text { The environment (air, water, inert surfaces) is the major source of } \\
\text { bacteria responsible for Nosocomial infection. }\end{array}$ & 24.1 & 48.4 & 6.0 & 20.2 \\
\hline $\begin{array}{l}\text { Advanced age or very young age increases the risk of nosocomial } \\
\text { infection }\end{array}$ & 74.1 & 93.5 & 71.0 & 69.3 \\
\hline Invasive procedures increase the risk of nosocomial infection & 86.4 & 96.8 & 70.6 & 86.0 \\
\hline $\begin{array}{l}\text { Precaution standards - Include the recommendations to protect only } \\
\text { the patients }\end{array}$ & 89.5 & 84.0 & 88.2 & 91.2 \\
\hline $\begin{array}{l}\text { Precaution standards - Include the recommendations to protect the } \\
\text { patients and the healthcare workers. }\end{array}$ & 96.3 & 90.3 & 94.1 & 98.2 \\
\hline Precaution standards - Apply for all the patients & 96.3 & 93.6 & 94.1 & 96.3 \\
\hline $\begin{array}{l}\text { Precaution standards - Apply for only healthcare workers who have } \\
\text { contact with body fluid }\end{array}$ & 76.5 & 74.2 & 82.4 & 76.0 \\
\hline $\begin{array}{l}\text { Hand Hygiene - When is hand hygiene recommended? Before or } \\
\text { after a contact with (or care of) a patient. }\end{array}$ & 72.8 & 58.1 & 64.7 & 78.1 \\
\hline $\begin{array}{l}\text { Hand Hygiene - When is hand hygiene recommended? Between } \\
\text { patient contacts }\end{array}$ & 90.7 & 96.8 & 82.4 & 90.4 \\
\hline $\begin{array}{l}\text { Hand Hygiene - When is hand hygiene recommended? After the } \\
\text { removal of gloves }\end{array}$ & 87.7 & 96.8 & 76.5 & 86.8 \\
\hline $\begin{array}{l}\text { Hand Hygiene- What are the indications for the use of alcohol- } \\
\text { based hand rub (on unsoiled hands)? }\end{array}$ & 33.9 & 19.7 & 58.9 & 34.2 \\
\hline $\begin{array}{l}\text { Protective barriers - The standard precautions recommend use of } \\
\text { gloves: } \\
\text { - For each procedure, } \\
\text { - When there is a risk of contact with the blood or body fluid, } \\
\text { - When there is a risk of a cut, When healthcare workers have a } \\
\text { cutaneous lesion }\end{array}$ & 42.0 & 58.1 & 41.2 & 37.7 \\
\hline $\begin{array}{l}\text { The care of equipment: The care of equipment involves the } \\
\text { appropriate disposal of waste, contaminated laundry and sharp; the } \\
\text { cleaning, sterilization and disinfection of equipment, instruments and } \\
\text { devices. The health worker should: } \\
\text { - Reuse equipment even if they are not visibly blood stained, }\end{array}$ & 71.0 & 77.4 & 58.8 & 71.1 \\
\hline $\begin{array}{l}\text { The care of equipment: The care of equipment involves the } \\
\text { appropriate disposal of waste, contaminated laundry and sharp; the } \\
\text { cleaning, sterilization and disinfection of equipment, instruments and } \\
\text { devices. The health worker should: } \\
\text { - If facility does not have autoclave, disinfection alone can make } \\
\text { equipment safe, }\end{array}$ & 71.0 & 77.4 & 58.8 & 71.1 \\
\hline
\end{tabular}




\begin{tabular}{|c|c|c|c|c|}
\hline Infection prevention and control categories & $\begin{array}{c}\text { Total } \\
(\%)\end{array}$ & $\begin{array}{c}\text { Medicine } \\
(\%)\end{array}$ & $\begin{array}{c}\text { Radiology } \\
(\%)\end{array}$ & $\begin{array}{c}\text { Nursing } \\
(\%)\end{array}$ \\
\hline $\begin{array}{l}\text { The care of equipment: The care of equipment involves } \\
\text { the appropriate disposal of waste, contaminated laundry } \\
\text { and sharp; the cleaning, sterilization and disinfection of } \\
\text { equipment, instruments and devices. The health worker } \\
\text { should: } \\
\text { - Should follow manufacturer and facility protocols in all } \\
\text { instances }\end{array}$ & 71.0 & 77.4 & 58.8 & 71.1 \\
\hline $\begin{array}{l}\text { The care of equipment: The care of equipment involves } \\
\text { the appropriate disposal of waste, contaminated laundry } \\
\text { and sharp; the cleaning, sterilization and disinfection of } \\
\text { equipment, instruments and devices. The health worker } \\
\text { should: } \\
\text { - High level disinfection can be achieved using } \\
\text { glutaraldehyde }\end{array}$ & 71.0 & 77.4 & 58.8 & 71.1 \\
\hline $\begin{array}{l}\text { The care of equipment: The care of equipment involves } \\
\text { the appropriate disposal of waste, contaminated laundry } \\
\text { and sharp; the cleaning, sterilization and disinfection of } \\
\text { equipment, instruments and devices. The health worker } \\
\text { should: } \\
\text { - Metallic equipment can be disinfected using hypochlorite }\end{array}$ & 71.0 & 77.4 & 58.8 & 71.1 \\
\hline $\begin{array}{l}\text { Health practices: Health workers who believe they have } \\
\text { been contaminated with an infectious agent should } \\
\text { - Keep this information themselves }\end{array}$ & 88.3 & 93.6 & 94.1 & 86.0 \\
\hline $\begin{array}{l}\text { Health practices: Health workers who believe they have } \\
\text { been contaminated with an infectious agent should } \\
\text { - Contact their primary health care provider or an } \\
\text { occupational health department for follow up and advice, }\end{array}$ & 88.3 & 93.6 & 94.1 & 86.0 \\
\hline $\begin{array}{l}\text { Health practices: Health workers who believe they have } \\
\text { been contaminated with an infectious agent should } \\
\text { - Assess the risk of transmitting the infectious agent to } \\
\text { patients only }\end{array}$ & 88.3 & 93.6 & 94.1 & 86.0 \\
\hline $\begin{array}{l}\text { Health practices: Health workers who believe they have } \\
\text { been contaminated with an infectious agent should } \\
\text { - Assess the risk of transmitting the infectious agent to } \\
\text { others (patients and other health workers) only, }\end{array}$ & 88.3 & 93.6 & 94.1 & 86.0 \\
\hline $\begin{array}{l}\text { Health practices: Health workers who believe they have } \\
\text { been contaminated with an infectious agent should } \\
\text { - Assess the risk of transmitting the infectious agent to } \\
\text { others (patients and other health workers) and take } \\
\text { appropriate precautions }\end{array}$ & 88.3 & 93.6 & 94.1 & 86.0 \\
\hline $\begin{array}{l}\text { Health practices: Health workers who believe they have } \\
\text { been contaminated with an infectious agent should } \\
\text { - Not Know and review their immunization status with } \\
\text { their primary health care provider }\end{array}$ & 88.3 & 93.6 & 94.1 & 86.0 \\
\hline
\end{tabular}

\section{Discussion}

Due to inadequate resources, the number of occupationally acquired infections like HIV and Hepatitis B has become a major concern for both the health care workers and the public. The history of transmission of infectious diseases like leprosy, syphilis, bubonic plague, and lately Hepatitis, HIV, Severe Acute Respiratory Syndrome (SARS), Methicillin Resistant Staphylococcus (MSRA), and
Vancomycin Resistant Enterococcus (VRE) has repeatedly shown that despite varying degrees of negative attitudes and unwillingness to care for patients by the public and health care workers, proper education about risks and advances in methods of prevention have served to change negative attitudes and promote a safer care-giving environment". 
Much as knowledge of IPCs is vital to all health workers, our study appears to show that there is higher knowledge among medical students compared to nursing/radiography students (though even this is limited by small numbers of medical and radiography students).

There is an increasing number of health care workers (HCWs) both in developed and developing countries who have been exposed to infection to blood-borne pathogens while caring of patients ${ }^{10}$.

Hands of medical workers, including medical students, transmit infections to and from patients. Physicians have been cited to be familiar with guidelines and knowledgeable about hand hygiene, however there are still significant knowledge gaps. Hand hygiene is key to the prevention of spread of micro-organisms responsible for endemic nosocomial infections, but frequently, this is not adequately recognised or appreciated by HCWs ${ }^{11,12}$.

From this study the mean overall score for the infection prevention and control knowledge $(67 \pm 2 \%)$ was low compared to a study where 80 to $90 \%$ of students showed good level of knowledge and awareness as well as perception about its importance in clinical practice ${ }^{13}$.

Medical students had a better mean score (72.9 \pm 5.3) than nursing students $(65.8 \pm 2.7)$ and radiologist students $(60.9 \pm 7.5)$. The Knowledge on IPCs was statistically equivalent for the nursing and radiologist students and for both males and females students. It was also found that the knowledge on infection prevention and control is equivalent among the students coming from urban and rural high schools. We believe this is the first study to compare knowledge of IPCs among these groups.

Students' knowledge differed according to specific areas of infection prevention and control and area of studies. Our results appeared to be similar and different in some ways to those reported by Marie-Pierre Tavolacci et al . Our results shown that the medical students had better overall score than nursing students and radiologist students, but MariePierre Tavolacci et al. found that the nursing students had a better overall score than did physiotherapist students, medical students and assistant radiologist students. Our results were also similar to theirs in that the overall score did not differ between male and female students.

Knowledge of guidelines has been associated with better hand-hygiene practices; therefore we think that efforts need to be focused to raise awareness regarding the impact of healthcare associated infections and implications of hand hygiene by holding seminars and group discussions and providing written instructions and posted reminders ${ }^{14,15}$. Studies have consistently identified improvement in overall hand-hygiene practices by interventions targeting at improving knowledge among healthcare workers ${ }^{16}$.

\section{Conclusion}

We found that knowledge about IPCs and awareness of its importance among health science students was below previously published studies on this topic, especially for nursing and radiology students in our survey. Further, it may not translate into good hand washing practice if the uptake is poor.

Marie-Pierre Tavolacci et al. recommended including pragmatic presentation of effective hand hygiene and standard precautions, feedback from teachers at the bedside, and inclusion of hygiene scores for students in all clinical training courses. They also recommend the strengthening of teaching, particularly with respect to the application of standard precautions for every patient, hand hygiene after use of gloves, and the benefit of using alcohol-based hand rub to decrease the transmission of nosocomial infection ${ }^{1}$.

Most students interviewed appreciated the knowledge and attitude toward IPCs and were eager to learn. They however attributed the low knowledge and attitude to lack of initiating IPCs early in the beginning of the course.

\section{Recommendations}

The Faculty of Health Sciences should introduce the module of IPCs at the earliest opportunity to health sciences students at the school.

The Faculty of Health Sciences should stress the importance of hand washing among health sciences students and should make it compulsory that health sciences students carry alcohol sanitizers.

In conjunction with the recent rise of pandemics, hospitals should take initiative to mandate infection control guidelines to students before entering the wards.

Ministry of Health and Social Services in conjunction with hospitals should intensify hand washing in clinical settings.

Teaching methods should be improved or modified to increase knowledge of infection control

Inter- professional approach to learning about significance of hand-washing should be encouraged. 


\section{References}

1. Marie-Pierre Tavolacci, Joël Ladner, Laurent Bailly, Véronique Merle, Isabelle Pitrou, Pierre Czernichow. Prevention of Nosocomial Infection and Standard Precautions: Knowledge and Source of Information Among Healthcare Students. Infection Control and Hospital Epidemiology, 2008; 29(7): 642-647.

2. C.Doig. Education of medical students and house staff to prevent hazardous occupational exposure. CMAJ 2000; 162: 344-345. NIOSH. Preventing needle stick injuries in health care settings. US. Department of Health and Human Services. Cincinnatti: DHHS (NIOSH) Published 1999.

3. Ministry of Health and Social Services, National Guidelines for Management of Tuberculosis, Third Edition, Windhoek. March 2012

4. Sissolak D, Bamford CM, Mehtar S: The potential to transmit Mycobacterium tuberculosis at a South African tertiary teaching hospital. Int J Infect Dis 2010; 14:e423-e428

5. Salim S. Abdool Karim, Rajendra Thejpal and Bipra Singh, High Prevalence of Hepatitis B Virus Infection in Rural Black Adults in Mseleni, South Africa. AJPH, Vol. 79, No. 7. Available from URL: http:// www.ncbi.nlm.nih.gov/pmc/articles/ PMC1349678/pdf/amjph00233-0093.pdf

6. Joubert JJ, Prozesky OW, Lourens JGH, van Straten AMJ, Theron JW, Swanevelder C, Meenehan GM, van der Merwe CA: Prevalence of hepatitis virus and some arbovirus infections in Kavango, northern SWA/Namibia. $S$ Afr Med J 1985; 67:500-502.

7. P. Mathur, "Hand hygiene: back to the basics of infection control," Indian Journal of Medical Research, 2011; 134(11): 611-620,.

8. S. Kelcíkova, Z. Skodova, S. Straka. Effectiveness of hand hygiene education in a basic nursing school curricula," Public Health Nursing 2012; 29 ( 2): 152-159.

9. World Alliance for Patient Safety. WHO guidelines on hand hygiene in health care advanced draft a summary: Clean hands are safer hands. World Health Organization. (Online) (Cited 2009 February 20). Available from URL: http: / / whqlibdoc.who.int/hq/2005/ WHO_EIP_SPO_QPS_05.2.pdf.

10. Adam Tucker, William R. Phillips, Medical students and infection control: risks and precautions Tokai J Exp Clin Med. 1999; 24( 4): 169-176,

11. Ippolito G, Puro V, HeptonstallJ, Jagger J, De G Carli, Petrosillo N. Occupational Human Immunodeficiency Virus Infection in Health Care Workers: Worldwide Cases through September 1997. Clin. Infec. Diseses. 1999; 28: 36583.

12. Pittet D. Compliance with hand disinfection and its impact on hospital-acquired infections. J Hosp Infect 2001; 48(Suppl. A):S40-6;

13. Larson E, Kretzer EK. Compliance with handwashing and barrier precautions. J Hosp Infect 1995; 30(Suppl.):88-106.)

14. Sulaiha S A, Wee Yun Ling, Lie Joo Chin, WeiLiang Eow, MuhamadFaiz S, Noris Chien Fook Tan, The Lack of Effective Hand Washing Practice Despite High Level Of Knowledge And Awareness In Medical Students Of Clinical Years, IeJSME 2010; 4(2): 18-26

15. Lam BC, Lee J, Lau YL. Hand hygiene practices in a neonatal intensive care unit: a multimodal intervention and impact on nosocomial infection. Pediatrics 2004; 114: 565-71.

16. Danchaivijtr S, Pichiensatian W, Apisarnthanarak A, Kachintorn K, Cherdrungsi R. Strategies to improve hand hygiene practices in two university hospitals. J Med Assoc Thai 2005; 88 Suppl 10: S155-60. 